\title{
State Responsibility Towards the Right to Health in the Age of Covid-19 Pandemic in Indonesia
}

\author{
Azhari Yahya ${ }^{1, *}$ \\ ${ }^{1}$ Faculty of Law, Syiah Kuala University \\ *Corresponding author. Email: azhari.yahya@unsyiah.ac.id
}

\begin{abstract}
The right to health is universally recognized through Article 25 paragraph (1) of Universal Declaration of Human Rights saying that everyone has the right to a standard of living adequate for the health and wellbeing of himself and of his family, including food, clothing, housing and medical care and necessary social services, and the right to security in the event of unemployment, sickness, disability, widowhood, old age or other lack of livelihood in circumstances beyond his control. Every country in the world including Indonesia that becomes a party to human rights treaty has addressed health-related rights including the right to health and a number of rights related to conditions necessary for health. Right to health encompasses all socio-economic, environmental and legal issues that have any direct implication on health. Therefore, the steps to be taken by the states parties shall include prevention, treatment and control of epidemic, endemic, occupational and other diseases. Under this framework, the state has duties to ensure the rights of its citizens to enjoy healthy life. In this matter, the state is duty-bound legally to provide basic minimum rights for securing health, including easily accessible and affordable good quality health care for all. Since Indonesian government had declared corona virus disease 2019 (Covid-19) as a national disaster on 2nd March 2020, every facet of society has changed dramatically. Consequently, Indonesian citizens feel threatened by the virus. Then, late response from the government has made them vulnerable to the pandemic. It was not until 13th March 2020 the Indonesian government reacted to the crisis by setting up the Task Force for Rapid Response to Covid-19 under Presidential Decree Number 9 year 2020. By then, the spread of corona virus becomes a core concern for Indonesian Government. Indonesian Task Force for Rapid Response to Covid-19 announced that as of 25th October 2020 there were 389,712 people were infected by Corona virus. Among them 313,764 people were recovered (80.51\%) and 13,299 people died $(3.41 \%)$ and 62,649 people were hospitalized $(16.07 \%)$. These data have made Indonesia as one of the most vulnerable countries in the world. The increase in death cases in Indonesia should be a worrying sign for Indonesian Government and now the government is entering a situation of being alert to the spread of this corona virus. In anticipating this situation Indonesian Government has implemented several recommendations for the prevention of this virus outbreak centrally through the health protocol. Society is obliged to apply social distance, selfisolation, clean living behaviors, and healthy living with nutritious food consumption. In short, the government must take a full role in providing alternatives as the way out to ensure the right to health for all citizens. Drawing on the above description, this paper scrutinizes the state responsibility in terms of providing health care for all citizens as human rights during Covid-19 pandemic in Indonesia.
\end{abstract}

Keywords: state responsibility, right to health, covid-19, pandemic.

\section{INTRODUCTION}

In early 2020 China has raised an alarm to the world about the dangers of SARS-Cov-2 or Corona Virus Disease 2019 (COVID-19). The Covid-19 outbreak, which has been declared by World Health Organization as a pandemic, has made 217 countries in the world strive to protect their citizens [1]. In Indonesia, since the first Covid-19 patient was announced by President Jokowi on March 2, 2020 |, national media coverage of this pandemic has never \ 
seemed to be successful [2]. Various elements of society also commented on the steps to be taken by the Government in emergency condition. This condition is getting worse when the President chose to impose Large-Scale Social Restriction since March 31, 2020 through Government Regulation Number 21 of 2020. With the implementation of Large-Scale Social Restrictions and work from home, both workers who work in the formal and informal sector decreased that their revenue significantly drop [3]. Data as of $25^{\text {th }}$ October 2020 shows that the number of Covid-19 cases in Indonesia was recorded at 38 9,712 people. Among of these 313,764 people $(80.51 \%)$ were recovered, 13,299 people $(3.41 \%)$ died, and 62,649 people $(16.07 \%)$ were in care [4].

Huge number of Covid-19 cases that occurred in Indonesia could be due to delay in handling the cases by the state. Delays and lack of information regarding the way to handle the cases can be harmful all people because public do not really know how to prevent Covid cases step by step [5]. This pandemic as a health emergency situation does not only affect health alone, but also economic and social problems. Therefore, the actions and policies taken to deal with covid-19 must be proportional, and care about human rights, especially right to health which are protected and guaranteed by the constitution [6].

The reports released by some organizations show that there are many problems faced in the field in handling Covid pandemic in Indonesia, among others lack of medical staff, lack of health facilities, lack of health infrastructure, lack of health services, the lack of community access to health care by which it is an integral part of human rights [7]. In the context of handling Covid-19 pandemic, current and reliable information regarding the pandemic situation must be fully provided to the public without any exception. This is considered really important because in the absence of Covid-19 vaccines rights now, the safety of citizens becomes a top priority that should be taken care by the government [8]. In this regards, the important point that needs to be fully considered is that how to fulfill the right to health for all citizens.

In handling this pandemic, one of the basic principles that must be met is that the State has the obligation to fulfill the rights to health for all citizens. This principle is in line with the General Comment of The United Nations Number 14 concerning the Right to Highest Standard of Health which states that the state is obliged to pay attention to the availability, accessibility, acceptability, and quality of health services to the public [9]. Lack of preparation in handling Covid-19 by the state can result in serious impact for public such as uncontrolled number of Covid-19 victims that spread and transmit in the community. In line with the General Comment above, the Law Number 36 of 2009 concerning Health through Article 155 states that the Government regularly announces the type and spreads of disease that potentially infects and spreads in a short period of time.

Not only that, Article 9 paragraph (2) letter d Law Number 14 of 2008 concerning Openness of Public Information, Article 19 of Law Number 12 of 2005 concerning the Ratification of the International Covenant on Civil and Political Rights, and Article 14 of the Law Number 39 of 1999 concerning Human Rights also emphasizes that citizens have the rights to seek, obtain, possess, store, process and convey the necessary information including information on health. Therefore, the main issue which is interesting to be highlighted in this paper is that how does the implementation of state responsibility towards the right to health in the age of Covid-19 pandemic in Indonesia?

\section{THE RIGHT TO HEALTH AS HUMAN RIGHTS}

Health is good health condition, both physically, mentally, spiritually and socially to enable more people to live socially and economically productive (Article 1 point 1 Law Number 36 of 2009). Therefore, health is the basis of recognition of the degree of humanity. Without health, a person is conditionally unequal and he will not be able to obtain other rights [10]. A person who is not healthy will automatically reduce his right to life, cannot obtain and carry out a decent job, cannot enjoy his right to associate and gather and express opinions, and cannot obtain education for his future [11]. In short, without health, a person will not be able to fully enjoy life as a human being.

The right to health becomes fundamental and invaluable human rights for the implementation of other rights. In other words, the human degree of a person is determined by the level of education and health, so that education and health are human rights with all other rights [12]. Legally everyone has the right to enjoy the highest standard of health that is affordable and conducive to an equal human life that must be realized in accordance with nation philosophy [13]. Thus, the right to health can be interpreted as a part of a set of rights that inherent in human existence as a creature of God the Almighty. This right which is a gift from the God Almighty must be respected, upheld and protected by the state, law, government, and everyone for the sake of human dignity [14].

Therefore, it is needed serious efforts from the state to implement the right to health to the maximum level and no action should be done to reduce, impede, 
restrict, or revoke the right to health as part of human rights. The right to health is expressly guaranteed in legal instrument of human rights both nationally and internationally [15]. National instruments refer to the provisions of Article $28 \mathrm{H}$ paragraph (1) 1945 Constitution which is followed up in Article 9 paragraph (3) Law Number 39 of 1999 concerning Human Rights and Law Number 36 of 2009 concerning Health.

In international instrument of human rights, right to health is stipulated in Article 25 paragraph (1) of the Universal Declaration of Human Rights which states that "Everyone has the right to a standard of living adequate for the health and well-being of himself and of his family, including food, clothing, housing and medical care and necessary social services, and the right to security in the event of unemployment, sickness, disability, widowhood, old age or other lack of livelihood in circumstances beyond his control".

The above article illustrates that every person has the right to a standard of living that is adequate for the health and welfare of himself and his family, including the right to food, clothing, housing, health and social security at times of unemployment, illness, disability, and old age. However, all the rights mentioned above cannot be enjoyed without having adequate health. Therefore, health is very important because it is a prerequisite for someone to be able to achieve maximum dignity in his life [16]. Guarantee of the right to health is also contained in Article 12 paragraph (1) of the International Convention on Economic, Social and Cultural Rights enacted by the United Nations General Assembly 2200 A (XXI) dated December 16, 1966 by which participating states to the convention recognize the rights of everyone to enjoy the highest attainable standard of physical and mental health [17].

Other international instruments on the right to health are also contained in Articles 12 and 14 of the International Convention on the Elimination of All Forms of Discrimination against Women. Article 12 creates the obligation of states parties to "take all appropriate measures to eliminate discrimination against women in the field of healthcare in order to ensure access to health care services, including those related to family planning". Then, Article 14 of the Convention provides protection for rural women and their special problems, ensuring the rights of women to participate in development programs, to have access to adequate health care facilities, to participate in all community activities, to have access to agricultural credit, to enjoy adequate living conditions. Right to health covers a wide area of economic and social factors that affect the creation of conditions in which people can achieve a healthy life. The fulfillment of the right to health is highly dependent on other determining factors such as food, nutrition, shelter, drinking water, adequate sanitation, working conditions and environment [18].

Right to health this cannot be interpreted as a right to be healthy, but it is the right to access to health facilities. The right to health contains the right to freedom and the right to obtain something that supports health [19]. Freedom includes the right to check the health of the body, including sexual health, the right to reproduction, the right to be free from interruption or interference of others, the right to freedom from torture, freedom from medical treatment without consent and experimentation, and the right to the protection system health that provides equal opportunities for everyone to meet adequate health standards [20].

Right to health depends on many factors that exist in a person such as genetic inheritance, body condition and lifestyle. Then, right to health must be understood as the right to be able to enjoy various facilities of health, health services and other conditions needed to achieve health standards that are affordable to each individual. In addition, it should be also understood that right to health is not only related to health care itself, but also other factors that come decisive to the health condition of individual including clean air, clean house which is free from diseases, healthy sanitation and others.

\section{GLOBAL PANDEMIC AND THE POLICY IN INDONESIA}

On $10^{\text {th }}$ March 2020, the Director General of the World Health Organization (WHO) sent a letter to the President of the Republic of Indonesia to ask the level of Indonesia's readiness to face the global pandemic. Following up this letter, President of the Republic of Indonesia issued Presidential Decree Number 12 of 2020 concerning non-natural disasters caused by Corona Virus. This Decree was signed by the President on $13^{\text {th }}$ April 2020. This policy was certainly very late because the country of origin of the virus has announced 4 months previously about the dangers of this virus. WHO itself has given a loud and clear warning about the danger of Corona Virus since $12^{\text {th }}$ March 2020.

The confidence of the Minister of Health of the Republic of Indonesia to handle Covid-19 pandemic at the beginning was proven wrong. Mistakes are common, especially in the cace of corona virus which is unpredictable and difficult to control. However, the most important thing is that how the government can deal with and stop the spread of corona virus, which is already at the national critical point [21]. President 
Jokowi's policy at the beginning of the spread of corona virus which was handed over to local governments and community was quite unfortunate. It has been understood that the potential and situation of areas related to corona are different from one region to another. It is possible that there are some areas that are already under emergency of corona virus; on the other hand there are also some areas that are less affected by corona virus.

In addition, limited resources owned by the regions also may affect the quality of handling corona virus in the community. Therefore, it is quite reasonable for the central government to take over the handling of corona virus into national policy [22]. In this condition, the government has the responsibility to play a full role in finding alternative solutions because the fulfillment of the right to health is one of the rights guaranteed in the 1945 Constitution.

Efforts to fulfill the right to health can be carried out in various ways, namely in the form of prevention and curative. Prevention efforts include creating conditions that are adequate for health, ensuring the availability of food and jobs, ensuring the availability of good housing and a healthy environment. Meanwhile, curative efforts are carried out by providing optimal health services [23] . Regarding corona virus which has become pandemic, the government is expected to take strategic steps to heal people who have been stranded due to this corona virus.

In handling this corona virus, the government based on Article 154 Law Number 36 of 2009 concerning Health, must publish a region which is the source of disease transmission to the public. In this case the government must disclose the type and spread of disease which are potentially carry infectious within short period of time, and mention which areas are the source of infections [24]. The government shall determine disaster emergency status according to the scale of disaster. For disasters on a national scale it is determined by the President, for disasters on a provincial scale determined by the Governor, and for disasters on a district/city scale are determined by the head of district/Mayor.

The determination of the emergency status of the disease outbreak due to corona virus was based on the decision made by Ministries/Institutions at the Office of the Coordinating Ministry for Human Development and Culture on $28^{\text {th }}$ January 2020. The government has declared Covid-19 as a certain emergency situation for disease outbreaks. What it is meant by a certain condition is that a state has not been determined or the status of a disaster emergency that has been lost and extended, however it is still necessary to reduce the risk of a disaster with a wide impact.
Certain emergencies then proceed to become catastrophic emergency. What it is meant by catastrophic emergency is a situation that threatens and disrupts the lives and livelihoods of a group of people who require immediate and adequate action which includes emergency response and emergency transition to recovery [25]. This status was determined by the National Disaster Management Agency through Decree Number 13A of 2020 concerning the Extension of the Status of Certain Disaster Emergency Conditions for Disease Outbreaks due to the Corona Virus in which the government determined Covid-19 disease as a certain emergency situation for a disease outbreak. This status was valid until $29^{\text {th }}$ May 2020.

The authority to declare a disaster due to Covid-19 pandemic as national emergency is the authority of the President. This authority is in line with the provisions of Article 51 of Disaster Management Law Number 24 of 2007 considering that Covid-19 outbreak has become a global pandemic in which this virus has spread to various regions. The imposition of activity restrictions in the response and prevention of the spread of the corona virus has caused serious impacts. This impact mostly hits small and medium enterprises that are affected by the establishment of emergency status that lead to limit community activities [26]. This condition has resulted in many business actors are unable to meet their daily needs and surrender to the situation.

In relation to Covid-19 pandemic the facts show that countries of origin of the virus have announced internationally to be prepared for a rapid spreading virus and WHO also has emphasized that "weak detection in the early stages of the outbreak may results in a significant increase in the number of cases of death ". Related to this matter, Article 5 paragraph (1) of Law Number 4 of 1984 concerning Contagious Disease Outbreaks has regulated that in any disaster condition the following efforts need to be taken, namely: (a). epidemiological investigations; (b). examination, treatment, care and isolation of patients, including quarantine measures; (c). prevention and immunization; (d). elimination of disease causes; (e). handling of bodies due to the plague; (f). outreach to the community; $(\mathrm{g})$. other countermeasures.

\section{COVID-19, STATE RESPONSIBILITY AND THE WAY FORWARDS}

The state is an organization like a civil legal entity whose structure is formed according to public law or constitutional law. Meanwhile, the government is part of a state organization consisting of agencies, apparatus, agencies, positions, regions, regions and so on. As a legal entity, the state is responsible for its citizens [27]. One form of accountability that must be 
provided by the state to its citizens is health services in order to fulfill the rights to health of its citizens, which is one of the human rights.

The main basis is that the protection of human rights is the obligation of the government where the government is given the mandate of power to protect the rights of citizens. Moreover, the concept of a welfare state as a modern state concept has given more power to the government to act [28]. This power is solely for advancing and achieving the fulfillment of human rights. The government is no longer just safeguarding someone not to violate or have their rights violated, but must strive to fulfill these rights [29].

The health services that must be provided by the state include aspects of social security for health, adequate health facilities, qualified medical personnel, and service financing that is affordable to the community. In this case the steps that must be taken to achieve the highest standards in attaining physical and mental health among others are: 1). Improvement of all aspects of environmental and industrial health; 2). Prevention, treatment and control of all endemic infectious diseases, work-related diseases and other diseases; 3). The creation of conditions which ensure the availability of all medical care and attention when disease occurs.

In this case Article 6 of Law Number 24 of 2007 on Disaster Management reiterated that the Government is responsible for organizing disaster in protecting public activities, ensure the fulfillment of the right of people affected by the disaster fairly in accordance with minimum standards minimum to reduce disaster risk. In global context, the state is obliged to provide protection for the right to health of its citizens as expressly stated in Article 25 paragraph (1) of the Universal Declaration of Human Rights which states: "Everyone has the right to a standard of living adequately for the health and wellbeing of himself and of his family, including food, clothing, housing and medical care and necessary social services, and the right to security in the event of unemployment, sickness, disability, widowhood, old age or other lack of livelihood in circumstances beyond his control" .

Following up the provisions of Article 25 paragraph (1) Universal Declaration of Human Rights above, the United Nations formulates further obligation of the state to provide protection of right to health of its citizens through Article 12 paragraph (2) point d, International Covenant on Economic, Social and Cultural Rights (ICESCR) 1966; and Article 12 point b General Comment Number 14 on Article 12 of the ICESCR by which Indonesia has ratified it through Law Number 11 of 2005. The above provisions oblige the state to strive for the improvement of all aspects of environmental and industrial health, prevention, treatment and control of all infectious, endemic and other occupational diseases, and the creation of conditions that will ensure all medical care and attention.

In this regard Article 55 Law Number 24 of 2007 on Disaster Management stating that the vulnerable groups which include the elderly, infants, toddlers, children, mothers that were pregnant as well as persons with disabilities shall be protected. In addition, Article 28 paragraph (4) 1945 Constitution stated that "the protection, advancement, upholding, and fulfillment of human rights is the responsibility of the state, especially the government ". This government's obligation is also emphasized in Article 8 of Law Number 39 Year 1999 concerning Human Rights which states that "protection, advancement, enforcement and fulfillment of human rights are primarily the responsibility of the Government".

In relation to the right to health which is part of Human Rights, Article 7 of Law Number 36 of 2009 concerning Health states that "Everyone has the right to receive balanced and responsible information and education on health". Furthermore, Article 9 paragraph (1) of the Law of Health states that "Every person is obliged to realize, maintain, and improve public health". This regulation also emphasizes that the government is responsible for improving the degree of public health and is obliged to provide health services so that people get adequate health protection as an inherent right. Therefore, proper protection and health insurance for every citizen become government's obligation.

The government's obligation to protect right to health is not only limited to provide health facilities, but is also obliged to ensure accessibility to health information. This accessibility is line with Article 12 paragraph (1) of ICESCR and Paragraph 12 (b) of General Comment Number 14 on Article 12 of ICESCR. Information that can threaten public's life including information related to epidemics and pandemics must be announced by the competent public body. This is also in line with the provisions of Article 12 of Information Commission Regulation Number 1 of 2010 concerning Public Information Service Standards, which obliges the government to provide information to the public.

Referring to Article 154 paragraph (1) Health Law Number 36 of 2009, the government is also obliged to determine and announce the types and spread of diseases that have the potential to be contagious and / or spread in a short time, as well as mention areas that can be sources of infection. This information disclosure is important and needed by all levels of society, especially by health workers who are at the forefront of handling outbreaks. The goal to be 
achieved from this legal norm is the realization of the state's responsibility to protect its citizens from all kinds of diseases, both those who live in the jurisdiction of the Indonesian territory and those who live outside the jurisdiction of the Indonesian state [31].

Therefore, in order to realize the right to health, the government must take at least 4 (four) actions, namely: (1) formulating provisions to reduce the rate of death birth of children; (2) make improvements to all aspects of environmental and industrial health; (3) prevent, treat and control all infectious, endemic and other occupational diseases, and (4) create conditions which will guarantee all medical care and attention in the event of a person's illness.

In addition to the above measures, the Government also needs to confirm the right to health in all forms and levels contains several important elements, namely: First, the availability of health care facilities, health goods and services must be sufficient. Second, the availability of adequate health accessibility for everyone without discrimination, where access to health must be accessible to all especially marginalized people. In addition, access to health must also be economically affordable for all and ensure that health services are available both privately and publicly for everyone including socially disadvantaged groups. Third, health facilities, goods and services must be accepted by the medical ethics. Fourth, health facilities, goods and services of health in the medical sciences must meet high quality of goods and services.

Efforts to fulfill the right to health can be carried out in various ways including prevention and curative [32]. Prevention efforts include the creation of conditions that are adequate for health, both ensuring the availability of food and jobs, good housing, and healthy environment. Meanwhile, curative efforts are carried out by providing optimal health services. Health services include aspects of social security for health, adequate health facilities, qualified medical personnel, and service financing which is affordable to the community.

The Law on Health regulates various kinds of efforts which are the responsibility of the government to achieve an optimal health degree. In general, Article 10 of the Health Law states that in order to achieve optimal health status for the community, health efforts are carried out with a maintenance approach, health promotion (promotion), disease prevention (preventive), disease healing (curative), and health restoration (rehabilitation) which are implemented thoroughly, integrated and continuously.

\section{CONCLUSION}

The Covid-19 pandemic not only affects health sector, but also all sectors of life. In the context of pandemic corona virus as declared by World Health Organization, the state has full obligation to overcome the pandemic outbreak. In this regards, the state's responsibility is not only limited to providing health services to residents affected by corona, but also supporting all factors that allow corona virus to be stopped from spreading. Therefore, in order to ensure this obligation, one of the principles that must be adhered is that health must remain oriented towards humanitarian services and the government is fully obliged to fulfill it.

It has been recognized that health is a primary priority to be put forward by the government because in the era of crisis situation all policy making have always encountered a dilemma. Therefore, every policy during the Covid-19 pandemic enacted by the government agencies are required to be harmonized with other policies and should lead to concrete steps to realize the right to health. One of the real manifestations that should be done by the government of Indonesia as a commitment to fulfill the right to health is to provide adequate budget for health facilities and services. By having this commitment is expected that the government would be able to tackle global pandemic promptly and accurately so that covid-19 would be eliminated soon and the impact caused by this corona virus is also would be eradicated immediately.

* A plenary paper presented in the International Conference on Law and Human Rights under the theme Reimagining the Vision on Law and Human Rights, organised by Research and Development Agency for Law and Human Rights, Ministry of Law and Human Rights \& Faculty of Law, Syiah Kuala University, Banda Aceh, Indonesia, on $26^{\text {th }}-27^{\text {th }}$ October 2020.

\section{REFERENCES}

[1]. https://www.worldometers.info/coronavirus/?ut m_campaign=homeAdvegas 1 ?\#countries

[2]. Apresian, S.R., 2020. Responding to the COVID-19 Outbreak in Indonesia: Lessons from European Countries and South Korea. Jurnal Ilmiah Hubungan Internasional, pp.5357.

[3]. Djalante, R. et al 2020. Review and analysis of current responses to COVID-19 in Indonesia: Period of January to March 2020. Progress in Disaster Science, p.100091. 
[4]. https://covid19.go.id/p/berita/pasien-sembuhharian-bertambah-4545-orang accessed 25 October 2020 at 11.58 PM.

[5]. Abbas, A., et al., 2020. The Involvement of Firms in Helping Fight the Pandemic of COVID-19: Evidence from Indonesia. Inovbiz: Jurnal Inovasi Bisnis, 8(1), pp.72-76.

[6]. Chinmi, M., et al., 2020. Exploring Online News as Comparative Study Between Vendatu at India and Ruangguru From Indonesia in Covid-19 Pandemic. Call for Papers, p.167.

[7]. Halabi, S.F., 2009. Participation and the right to health: lessons from Indonesia. health and human rights, pp.49-59.

[8]. Amon, J.J. and Wurth, M., 2020. A virtual roundtable on COVID-19 and human rights with human rights watch researchers. Health and Human Rights, 22(1), p.399.

[9]. Committee on Economic, Social and Cultural Rights, General Comment No. 14, The Right to the Highest Attainable Standard of Health, UN Doc. No. E/C,12/2000/4 (2000), available at: https://digitallibrary.un.org/record/425041?1 $\mathrm{n}=\mathrm{en}$

[10]. Amon, J.J., 2020. COVID-19 and detention: respecting human rights. Health and Human Rights Journal, 23.

[11]. Ayuningtyas, D., Haq, H.U. and Utami, R.R.M., 2020. Initiating Global Civil Society as a Strategy for Handling the COVID-19 Public Health Threat: A Policy Review. Kesmas: Jurnal Kesehatan Masyarakat Nasional (National Public Health Journal), 15(2).

[12]. Bachmann, S.D. and Sanden, J., 2020. State Responsibility for the (Public) Right to Health and Security in Times of COVID Pandemic: A European Perspective. Indon. J. Int'l \& Comp. L., 7, p.407.

[13]. Baker, P., White, A. and Morgan, R., 2020. Men's health: COVID-19 pandemic highlights need for overdue policy action. The Lancet, 395(10241), pp.1886-1888.

[14]. Leary, V.A., 1994. The right to health in international human rights law. Health and Human Rights, pp.24-56.

[15]. Pūras, D., de Mesquita, J.B., Cabal, L., Maleche, A. and Meier, B.M., 2020. The right to health must guide responses to COVID19. Lancet (London, England). See also Sen, A., 2008. Why and how is health a human right?. The Lancet, 372(9655), p.2010.

[16]. Tobin, J., 2012. The right to health in international law. Oxford University Press. See also Toebes, B., 2001. The right to health as a human right in international law. Refugee Survey Quarterly, 20(3).

[17]. International Covenant on Economic, Social and Cultural Rights and Political Rights (resolution 2200A (XXI) of 16 December 196, Art. $4 . \quad$ Available at https://www.ohchr.org/EN/ProfessionalInter est/Pages/CCPR.aspx.

[18]. Schiariti, V., 2020. The human rights of children with disabilities during health emergencies: the challenge of COVID19. Developmental Medicine \& Child Neurology, 62(6), pp.661-661.

[19]. Hamid, A.R.A.H., 2020. Social responsibility of medical journal: a concern for COVID-19 pandemic. Medical Journal of Indonesia, 29(1), pp.1-3.

[20]. Ruslina, E. and Sekarsari, R., 2020. Legal Protection of Medical Staff in Hospitals during The Covid-19 Pandemic Era. International Journal of Latin Notary, 1(1), pp.29-35.

[21]. Qodir, Z., et al 2020. Covid-19 and Chaos In Indonesia Social-Political Responsibilities. Journal of Talent Development and Excellence, 12(1), 46294642.

[22]. Nugroho, Y., \& Negara, S. D. (2020). Urgent Need to Strengthen State Capacity: Learning from Indonesia's COVID-19 Crisis.

[23]. Fortier, N., 2020. COVID-19, gender inequality, and the responsibility of the state. International Journal of Wellbeing, 10(3).

[24]. Runtunuwu, Y.B. and Sidayang, S., 2020, Implementation of Military Emergency in Indonesia to Handle Corona Virus Disease (Covid-19) in the Perspective of Human Rights. In 3rd International Conference on Social Sciences (ICSS 2020) (pp. 178-183). Atlantis Press.

[25]. Sulistiawati, L.Y., 2020. Indonesia's Legal Framework in Combating Covid-19.

[26]. Utama, I.M.A., 2020. Do Indonesian Laws and Policies on Covid-19 Countermeasures Action Reflect Legality?. Udayana Journal of Law and Culture, 4(2), pp.211-228.

[27]. ChaturvedI, I., 2020. China's State Responsibility for the Global Spread of COVID-19: An International Law Perspective.

[28]. Bergkamp, L., 2020. State Liability for Failure to Control the COVID-19 Epidemic: International and Dutch Law. European Journal of Risk Regulation, pp.1-7.

[29]. Kennedy, R., 2020. Legal Discourse on Manpower During COVID-19 Outbreak. Law Reform, 16(1), pp.70-86. 
[30]. Kupferschmidt, K. and Cohen, J., 2020. Can China's COVID-19 strategy work elsewhere?.

[31]. Wiratraman, H.P., 2020. Does Indonesian COVID-19 Emergency Law Secure Rule of Law and Human Rights?. JSEAHR, 4, p.306.

[32]. Rubenstein, L. \& DeCamp, M., 2020. Revisiting Restrictions of Rights After COVID-19. Health and Human Rights Journal 